\title{
High efficiency of livestock ammonia emission controls in alleviating particulate nitrate during a severe winter haze episode in northern China
}

\author{
Zhenying Xu ${ }^{1}$, Mingxu Liu ${ }^{1}$, Minsi Zhang ${ }^{2}$, Yu Song ${ }^{1}$, Shuxiao Wang ${ }^{3}$, Lin Zhang ${ }^{4}$, Tingting Xu ${ }^{1}$, Tiantian Wang ${ }^{1}$, \\ Caiqing Yan ${ }^{1}$, Tian Zhou ${ }^{1}$, Yele Sun ${ }^{5}$, Yuepeng Pan ${ }^{5}$, Min Hu${ }^{1}$, Mei Zheng ${ }^{1}$, and Tong Zhu ${ }^{1}$ \\ ${ }^{1}$ State Key Joint Laboratory of Environmental Simulation and Pollution Control, Department of \\ Environmental Science, Peking University, Beijing, 100871, China \\ ${ }^{2}$ CDM Management Center, National Center for Climate Change Strategy and International Cooperation (NCSC), China \\ ${ }^{3}$ State Key Joint Laboratory of Environment Simulation and Pollution Control, School of Environment, \\ Tsinghua University, Beijing, 100084, China \\ ${ }^{4}$ Laboratory for Climate and Ocean-Atmosphere Studies, Department of Atmospheric and Oceanic Sciences, \\ School of Physics, Peking University, Beijing, 100871, China \\ ${ }^{5}$ State Key Laboratory of Atmospheric Boundary Layer Physics and Atmospheric Chemistry, \\ Institute of Atmospheric Physics, Chinese Academy of Sciences, Beijing, 100029, China
}

Correspondence: Yu Song (songyu@pku.edu.cn), Shuxiao Wang (shxwang@tsinghua.edu.cn), and Mei Zheng (mzheng@pku.edu.cn)

Received: 29 August 2018 - Discussion started: 12 September 2018

Revised: 4 January 2019 - Accepted: 12 February 2019 - Published: 30 April 2019

\begin{abstract}
Although nitrogen oxide $\left(\mathrm{NO}_{x}\right)$ emission controls have been implemented for several years, northern China is still facing high particulate nitrate $\left(\mathrm{NO}_{3}^{-}\right)$pollution during severe haze events in winter. In this study, the thermodynamic equilibrium model (ISORROPIA-II) and the Weather Research and Forecast model coupled with chemistry (WRFChem) were used to study the efficiency of $\mathrm{NH}_{3}$ emission controls on alleviating particulate $\mathrm{NO}_{3}^{-}$during a severe winter haze episode. We found that particulate- $\mathrm{NO}_{3}^{-}$formation is almost $\mathrm{NH}_{3}$-limited in extremely high pollution but $\mathrm{HNO}_{3}$ limited on the other days. The improvements in manure management of livestock husbandry could reduce $40 \%$ of total $\mathrm{NH}_{3}$ emissions (currently $100 \mathrm{kt} \mathrm{month}^{-1}$ ) in northern China in winter. Consequently, particulate $\mathrm{NO}_{3}^{-}$was reduced by approximately $40 \%$ (on average from 40.8 to $25.7 \mu \mathrm{g} \mathrm{m}^{-3}$ ). Our results indicate that reducing livestock $\mathrm{NH}_{3}$ emissions would be highly effective in reducing particulate $\mathrm{NO}_{3}^{-}$during severe winter haze events.
\end{abstract}

\section{Introduction}

In northern China (including Beijing, Tianjin, Hebei, Shandong, Shanxi and Henan), severe haze pollution events occur frequently during wintertime, with the concentration of $\mathrm{PM}_{2.5}$ (particles with an aerodynamic diameter less than $2.5 \mu \mathrm{m}$ ) reaching hundreds of micrograms per cubic meter and SIA (secondary inorganic aerosol) accounting for more than $50 \%$ of $\mathrm{PM}_{2.5}$ (Zheng et al., 2016; Tan et al., 2018). To mitigate fine-particle pollution, the Chinese government has been taking strong measures to control $\mathrm{SO}_{2}$ emissions (http: //www.gov.cn/zwgk/2011-12/20/content_2024895.htm, last access: 5 January 2019). Since 2007, $\mathrm{SO}_{2}$ emissions have been reduced by $75 \%$ in China ( $\mathrm{Li}$ et al., 2017). Consequently, the particulate-sulfate concentration has also been declining continuously in the past decade (Geng et al., 2017).

Although $\mathrm{NO}_{x}$ emissions in 48 Chinese cities decreased by $21 \%$ from 2011 to 2015 (Liu et al., 2017a), unfortunately, no obvious decreasing trend for particulate $\mathrm{NO}_{3}^{-}$has been observed in northern China during recent years (Zhang et al., 2015). In October 2015, a severe haze episode was reported in the North China Plain 
(NCP), with the hourly peak concentration of particulate $\mathrm{NO}_{3}^{-}$exceeding $70 \mu \mathrm{g} \mathrm{m}^{-3}$ (Zhang et al., 2018b). Even in November 2018, during a heavy haze episode in northern China, the hourly peak concentration of $\mathrm{PM}_{2.5}$ still exceeded $289 \mu \mathrm{g} \mathrm{m}^{-3}$, of which particulate $\mathrm{NO}_{3}^{-}$accounted for $30 \%$ (http://www.mee.gov.cn/xxgk2018/xxgk/ xxgk15/201811/t20181116_674022.html, last access: 5 January 2019).

Another way to alleviate the particulate- $\mathrm{NO}_{3}^{-}$pollution is to control $\mathrm{NH}_{3}$ emissions. Previous studies were performed to demonstrate the necessity of $\mathrm{NH}_{3}$ emissions abatement in reducing $\mathrm{PM}_{2.5}$ concentrations in the United States (Pinder et al., 2007, 2008; Tsimpidi et al., 2007; Wu et al., 2016) and Europe (de Meij et al., 2009; Bessagnet et al., 2014; Backes et al., 2016). Recently, a feature article pointed out that $\mathrm{NH}_{3}$ could be key to limiting particulate pollution (Plautz, 2018). In contrast with low particulate matter pollution levels in the United States and Europe, what we are facing in northern China is the extremely high particulate- $\mathrm{NO}_{3}^{-}$pollution, especially during severe winter haze events.

Although Fu et al. (2017) proposed that the $\mathrm{NH}_{3}$ emission controls are urgently required in China, the effectiveness of $\mathrm{NH}_{3}$ emissions mitigation to alleviate the particulate- $\mathrm{NO}_{3}^{-}$ peaks during severe winter haze episodes was seldom reported. Only Guo et al. (2018) used a thermodynamic model to estimate the sensitivity of particulate $\mathrm{NO}_{3}^{-}$to TA (sum of ammonia and ammonium) during one winter haze episode in Beijing. In their study, the atmospheric chemistry simulations based on $\mathrm{NH}_{3}$ emission controls scenario were lacking to demonstrate the regional effects.

It is urgent to alleviate severe particulate- $\mathrm{NO}_{3}^{-}$pollution in northern China, and the study on the effectiveness on $\mathrm{NH}_{3}$ emission controls is necessary. In this study, we firstly compile a comprehensive $\mathrm{NH}_{3}$ emission inventory for northern China for the winter of 2015 and estimate the $\mathrm{NH}_{3}$ emission reductions by improving manure management. Then, the thermodynamic equilibrium model (ISORROPIA-II) and Weather Research and Forecast Model coupled with chemistry (WRF-Chem) are used to investigate the effectiveness of $\mathrm{NH}_{3}$ emission reductions in alleviating particulate $\mathrm{NO}_{3}^{-}$ during a severe haze episode. The molar ratio based on observations is used to explore the efficiency of particulate- $\mathrm{NO}_{3}^{-}$ reductions during the severe haze conditions in wintertime.

\section{Methods and materials}

\subsection{Observational data}

Hourly time-resolution aerosol and gas measurements were conducted at the Peking University urban atmosphere environment monitoring station (PKUERS) $\left(39.991^{\circ} \mathrm{N}\right.$, $116.313^{\circ} \mathrm{E}$ ) in Beijing in December 2015 and December 2016. A commercialized semicontinuous in situ gas and aerosol composition (IGAC) monitor was used to measure the concentrations of water-soluble ions (e.g., $\mathrm{NH}_{4}^{+}, \mathrm{SO}_{4}^{2-}$, $\left.\mathrm{NO}_{3}^{-}, \mathrm{Na}^{+}, \mathrm{K}^{+}, \mathrm{Ca}^{2+}, \mathrm{Mg}^{2+}, \mathrm{Cl}^{-}\right)$in $\mathrm{PM}_{2.5}$ and inorganic gases (e.g., $\mathrm{NH}_{3}, \mathrm{HNO}_{3}, \mathrm{HCl}$ ). Relative humidity (RH) and temperature were observed at $1 \mathrm{~min}$ resolution at the same site. The quality assurance and control for the IGAC was described in Liu et al. (2017b). A typical severe haze episode occurred from 6 to 10 December 2015, with daily average concentrations of $\mathrm{PM}_{2.5}$ exceeding $150 \mu \mathrm{g} \mathrm{m}^{-3}$ for 3 days $\left(\mathrm{PM}_{2.5}\right.$ data are from the China National Environmental Monitoring Centre). The average RH and temperature in this haze event were $60.9 \pm 11.4 \%$ and $276.5 \pm 1.4 \mathrm{~K}$. The south wind was dominant with wind speed mostly less than $3 \mathrm{~m} \mathrm{~s}^{-1}$. The average concentrations of particulate $\mathrm{NO}_{3}^{-}, \mathrm{NH}_{4}^{+}$and $\mathrm{SO}_{4}^{2-}$ were $39.8 \pm 14.7,27.7 \pm 8.6$ and

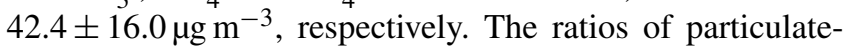
$\mathrm{NO}_{3}^{-}$concentrations to SNA (sulfate, nitrate and ammonium) were $36.5 \pm 4.0 \%$.

\section{$2.2 \quad \mathrm{NH}_{3}$ emission inventory}

A comprehensive $\mathrm{NH}_{3}$ emission inventory of northern China (including the six provinces mentioned above) in December 2015 at a monthly and $1 \mathrm{~km} \times 1 \mathrm{~km}$ resolution is developed based on our previous studies (Huang et al., 2012; Kang et al., 2016). This is a brief introduction to our inventory. More detailed descriptions and validation are found in our previous studies. Our $\mathrm{NH}_{3}$ emission inventory is a bottomup process-based and statistical model which considers a diverse range of sources, including both agricultural (livestock manure and chemical fertilizer) and nonagricultural sectors (traffic, biomass burning, etc.). According to our inventory, the estimated $\mathrm{NH}_{3}$ emission amount in northern China was $100 \mathrm{kt}$ in December 2015. The largest source was livestock waste ( $57 \mathrm{kt}, 57.0 \%$ of the total emissions), following by vehicle $(12.2 \%)$, chemical industry $(8.8 \%)$, biomass burning $(5.4 \%)$, waste disposal $(4.0 \%)$, synthetic fertilizer applications $(2.4 \%)$ and other minor sources $(9.1 \%)$. The proportion of chemical fertilizer is small due to the limited fertilization activity in winter. In the past few years, our inventory has been compared with many studies to prove its reliability. For example, the spatial pattern of $\mathrm{NH}_{3}$ emissions calculated in our inventory agreed well with the distribution of the $\mathrm{NH}_{3}$ column concentrations in eastern Asia retrieved from the satellite measurements of the Infrared Atmospheric Sounding Interferometer (IASI) (Van Damme et al., 2014). In particular, our estimation of livestock $\mathrm{NH}_{3}$ emissions in China is comparable to the results of Streets et al. (2003) and Ohara et al. (2007).

Another method for estimating $\mathrm{NH}_{3}$ emissions is the inverse modeling method, which provides top-down emission estimates through optimizing comparisons of model simulations with measurements. For example, Paulot et al. (2014) used the adjoint of a global chemical transport model (GEOS-Chem) and data of $\mathrm{NH}_{4}^{+}$wet deposition fluxes to optimize $\mathrm{NH}_{3}$ emissions estimation in China. Zhang et 
al. (2018a) applied the the Tropospheric Emission Spectrometer (TES) satellite observations of $\mathrm{NH}_{3}$ column concentration and GEOS-Chem to provide top-down constraints on $\mathrm{NH}_{3}$ emissions in China. Their estimates are 10.2 and $11.7 \mathrm{Tg} \mathrm{a}^{-1}$, respectively, which are close to our results $\left(9.8 \mathrm{Tg} \mathrm{a}^{-1}\right.$ ) (Paulot et al., 2014; Zhang et al., 2018a). The accuracy of this method relies on many factors, such as the accuracy of initial conditions, the emission inventories, meteorological inputs, reaction rate constants and deposition parameters in the chemical transport model. Errors in these parameters could cause biases in the top-down estimation of $\mathrm{NH}_{3}$ emissions. In addition, measurements of $\mathrm{NH}_{3}$ or $\mathrm{NH}_{4}^{+}$ used in this method, including surface and satellite date, are usually sparse in spatial coverage and have uncertainties, which will also affect the estimation of $\mathrm{NH}_{3}$ emissions.

\subsection{ISORROPIA-II and WRF-Chem models}

The thermodynamic equilibrium model, ISORROPIA-II (Fountoukis and Nenes, 2007), being used to determine the phase state and composition of an $\mathrm{NH}_{4}^{+}-\mathrm{SO}_{4}^{2-}-\mathrm{NO}_{3}^{-}-\mathrm{K}^{+}-$ $\mathrm{Ca}^{2+}-\mathrm{Mg}^{2+}-\mathrm{Na}^{+}-\mathrm{Cl}^{-}-\mathrm{H}_{2} \mathrm{O}$ aerosol system with its corresponding gas components in thermodynamic equilibrium, was used to investigate the response of particulate $\mathrm{NO}_{3}^{-}$to $\mathrm{NH}_{3}$ emission reductions. Using measurements of watersoluble ions, $T$ and RH from PKUERS as inputs and only including the thermodynamic equilibrium, ISORROPIA-II can avoid the inherent uncertainty in estimates of emission inventories, pollutant transport and chemical transformation. In this study, ISORROPIA-II was run in the "forward mode" and assuming particles are "metastable" with no solid precipitates, which is due to the relatively high $\mathrm{RH}$ range observed during this haze event $(\mathrm{RH}=60.9 \pm 11.4 \%)$.

We assess the performance of ISORROPIA-II by comparing measured and predicted particulate $\mathrm{NO}_{3}^{-}, \mathrm{NH}_{4}^{+}$and gaseous $\mathrm{HNO}_{3}$, and $\mathrm{NH}_{3}$. An error metric, the mean bias (MB), is used to quantify the bias (the description of MB is shown below Fig. S1 in the Supplement). The predicted particulate $\mathrm{NO}_{3}^{-}, \mathrm{NH}_{4}^{+}$and $\mathrm{NH}_{3}$ agree well with the measurements and the values of $R^{2}$ are $0.99,0.94$ and 0.84 , respectively (Fig. S1). The MB is only $1.0,0.3$ and $-1.8 \mu \mathrm{g} \mathrm{m}^{-3}$, respectively. However, the model performs poorly on $\mathrm{HNO}_{3}$, with an $R^{2}$ of only 0.06 and an MB of $-1.0 \mu \mathrm{g} \mathrm{m}^{-3}$. This is because particulate $\mathrm{NO}_{3}^{-}$is predominantly in the particle phase (the mass ratio of particulate $\mathrm{NO}_{3}^{-}$to the total nitric acid $\left(\mathrm{TN}=\mathrm{NO}_{3}^{-}+\mathrm{HNO}_{3}\right)$ was $\left.99.2 \pm 1.9 \%\right)$, and small errors in predicting particulate $\mathrm{NO}_{3}^{-}$are amplified in $\mathrm{HNO}_{3}$ predicting. Since the MB of $\mathrm{HNO}_{3}$ is much smaller than the observed particulate $\mathrm{NO}_{3}^{-}\left(39.8 \pm 14.7 \mu \mathrm{g} \mathrm{m}^{-3}\right)$ and $\mathrm{NH}_{4}^{+}$ $\left(27.7 \pm 8.6 \mu \mathrm{g} \mathrm{m}^{-3}\right)$, this bias has little influence on simulating the efficiency of particulate- $\mathrm{NO}_{3}^{-}$reductions.

In the real atmosphere, changes in the level of TA $\left(\mathrm{TA}=\mathrm{NH}_{4}^{+}+\mathrm{NH}_{3}\right)$ can affect the lifetime of $\mathrm{TN}$ (Pandis and Seinfeld, 1990). This is because the gaseous $\mathrm{HNO}_{3}$ has a faster deposition rate in the atmosphere than particulate
$\mathrm{NO}_{3}^{-}$, and reductions in $\mathrm{NH}_{4}^{+}$may prompt particulate- $\mathrm{NO}_{3}^{-}$ partitioning into the gas phase. In such a case, the concentration of TN would not remain constant but decrease. In order to consider these, we use WRF-Chem (version 3.6.1) to investigate the effect of $\mathrm{NH}_{3}$ emission controls on particulate$\mathrm{NO}_{3}^{-}$formation on the regional scale. The simulations were performed for the severe haze event from 6 to 10 December 2015. The modeling domain covered the whole of northern China with horizontal resolution of $25 \mathrm{~km}$ and 24 vertical layers from the surface to $50 \mathrm{hPa}$. The initial meteorological fields and boundary conditions were taken from the $6 \mathrm{~h}$ National Centers for Environmental Prediction (NCEP) global final analysis with a $1^{\circ} \times 1^{\circ}$ spatial resolution. The inorganic gas-aerosol equilibrium was predicted by the Multicomponent Equilibrium Solver for Aerosols (MESA) in WRF-Chem (Zaveri et al., 2005). The Carbon-Bond Mechanism version $\mathrm{Z}$ (CBMZ) photochemical mechanism and Model for Simulating Aerosol Interactions and Chemistry (MOSAIC) were used in this study (Fast et al., 2006). Anthropogenic emissions from power plants, industrial sites, residential locations and vehicles were taken from the Multiresolution Emission Inventory for China (MEIC; available at http://www.meicmodel.org/, last access: 5 January 2019).

The performance of WRF-Chem is evaluated by comparing measured and simulated $\mathrm{NO}_{3}^{-}, \mathrm{NH}_{4}^{+}, \mathrm{SO}_{4}^{2-}$ and TA. Specifically, the observed and simulated values are as follows: (1) $\mathrm{NO}_{3}^{-}-39.8 \pm 14.7 \mu \mathrm{g} \mathrm{m}^{-3}$ versus $39.1 \pm 15.6 \mu \mathrm{g} \mathrm{m}^{-3}$; (2) $\mathrm{NH}_{4}^{+}-27.7 \pm 8.6 \mu \mathrm{g} \mathrm{m}^{-3}$ versus $26.5 \pm 11.7 \mu \mathrm{g} \mathrm{m}^{-3}$; (3) $\mathrm{SO}_{4}^{2-}-42.4 \pm 16.0 \mu \mathrm{g} \mathrm{m}^{-3}$ versus $39.7 \pm 20.8 \mu \mathrm{g} \mathrm{m}^{-3}$; and (4) $\mathrm{TA}-34.6 \pm 8.5 \mu \mathrm{g} \mathrm{m}^{-3}$ versus $32.1 \pm 11.0 \mu \mathrm{g} \mathrm{m}^{-3}$. The MBs of these four species are -0.7 , $-1.2,-2.7$ and $-2.5 \mu \mathrm{g} \mathrm{m}^{-3}$, respectively. Simulated particulate $\mathrm{NO}_{3}^{-}, \mathrm{NH}_{4}^{+}, \mathrm{SO}_{4}^{2-}$ and TA approximately agreed with the measurements (Fig. S2). There are still some simulation biases that may affect the simulation of particulate- $\mathrm{NO}_{3}^{-}$reduction efficiency. This is discussed in detail in Sect. 3.3.

\section{Results}

\subsection{High-potential reduction in wintertime $\mathrm{NH}_{3}$ emissions in northern China}

Livestock husbandry accounts for the largest proportion of $\mathrm{NH}_{3}$ emissions in northern China in winter (approximately $60 \%$ ), which is mainly caused by poor manure management. There are three main animal rearing systems in China: freerange, grazing and intensive. On the one hand, the proportion of intensive livestock husbandry in China is only about $40 \%$, far lower than that of developed countries (Harun and Ogneva-Himmelberger, 2013). As a result, the widespread free-range and grazing animal rearing systems contribute more than half of the total livestock $\mathrm{NH}_{3}$ emissions due to a lack of manure collection and treatment (Kang et al., 2016). On the other hand, there were no relevant regulations about 
the storage of manure for intensive farms in China in the past few decades. This causes most livestock farms to also lack necessary measures and facilities for manure collection and storage (Chadwick et al., 2015).

Due to the current poor manure management in China, the improved manure management may have great potential for $\mathrm{NH}_{3}$ emission reductions from livestock husbandry (Wang et al., 2017). The improved manure management mainly includes three phases: in-house handling, storage and land application (Chadwick et al., 2011). For winter, the emission reduction measures mainly focus on in-house handling and storage, since land application mainly occurs in spring and summer. According to previous studies, for in-house handling, regularly washing the floor and using slatted floor or deep litter to replace solid floor could both reduce $\mathrm{NH}_{3}$ emissions by more than $50 \%$ (Groenestein and Van Faassen, 1996; Monteny and Erisman, 1998; Gilhespy et al., 2009; Hou et al., 2015). For storage, covering slurry and manure could reduce $\mathrm{NH}_{3}$ emissions by about $50 \%-70 \%$ (Balsari et al., 2006; Petersen et al., 2013; Hou et al., 2015; Wang et al., 2017).

Based on the above research results, the livestock $\mathrm{NH}_{3}$ emission reduction strategies applied in this study include the following steps. Firstly, the proportion of intensive livestock production was raised from $40 \%$ to $80 \%$ in our $\mathrm{NH}_{3}$ emission inventory model. In our model, the animals in free-range and grazing animal rearing systems are assumed to live outdoors for half a day, and the improved manure management is only effective for indoor animals. Therefore, increasing the proportion of intensive livestock production is conducive to better manure management (Hristov et al., 2011). Secondly, the ratios of $\mathrm{NH}_{3}$ emission reductions mentioned above were multiplied by $\mathrm{NH}_{3}$ emission factors in two phases of manure management: a $50 \%$ reduction for in-house handling and $60 \%$ (average value of $50 \%$ and a $70 \%$ ) reduction for storage. With these measures, we estimate that the $\mathrm{NH}_{3}$ emission factors for livestock in China could be comparable to those in Europe and the USA (shown in Table S1 in the Supplement). Meanwhile, our $\mathrm{NH}_{3}$ emission model predicted that the livestock $\mathrm{NH}_{3}$ emissions were reduced by $60 \%$ (from 57 to $23 \mathrm{kt}$ ), causing an approximately $40 \%$ reduction in total $\mathrm{NH}_{3}$ emissions. Spatially, $\mathrm{NH}_{3}$ emissions decreased significantly in Hebei, Henan and Shandong, where the livestock $\mathrm{NH}_{3}$ emissions accounted for a large proportion of the total (shown in Fig. S3).

\subsection{Simulations of $\mathrm{NO}_{3}^{-}$reduction due to $\mathrm{NH}_{3}$ emission controls}

In the ISORROPIA-II simulation, a $40 \%$ reduction in TA was used to reflect the effects of reducing $\mathrm{NH}_{3}$ emissions by $40 \%$. This approach has been used in many previous studies (Blanchard and Hidy, 2003; Vayenas et al., 2005). However, in the real atmosphere, the reductions in $\mathrm{NH}_{3}$ emission are not always equal to the reductions in TA due to the regional

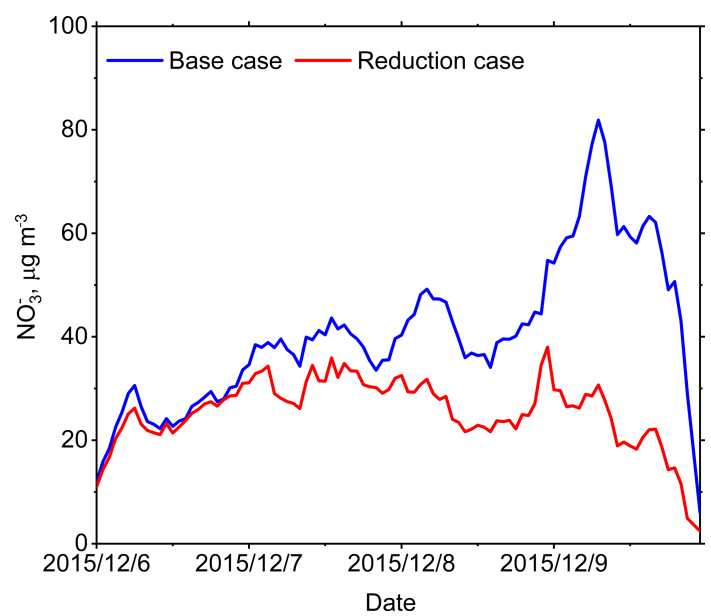

Figure 1. A comparison of particulate nitrate $\left(\mathrm{NO}_{3}^{-}\right)$between the base (blue line) and emission reduction cases (red line) simulated by the ISORROPIA-II model in this severe haze episode.

transmission. Their differences are discussed in the WRFChem simulation.

In this haze event (from 6 to 10 December 2015), the mean concentration of particulate $\mathrm{NO}_{3}^{-}$decreased from 40.8 to $25.7 \mu \mathrm{g} \mathrm{m}^{-3}$ (a $37 \%$ reduction). In addition, the peak hourly concentration of $\mathrm{NO}_{3}^{-}$decreased from 81.9 to $30.7 \mu \mathrm{g} \mathrm{m}^{-3}$ (a $63 \%$ reduction) (shown in Fig. 1). The fundamental thermodynamic processes of TA reductions in decreasing particulate $\mathrm{NO}_{3}^{-}$are explained below. Firstly, we found that $\mathrm{NH}_{3}$ was readily available to react with $\mathrm{HNO}_{3}$ in the thermodynamic equilibrium system because $\mathrm{NH}_{3}$ was $6.6 \pm 3.8 \mu \mathrm{g} \mathrm{m}^{-3}$ while $\mathrm{HNO}_{3}$ was only $0.4 \pm 1.1 \mu \mathrm{g} \mathrm{m}^{-3}$. Secondly, almost all particulate $\mathrm{NO}_{3}^{-}$condensed into the aerosol phase (the mass ratio of particulate $\mathrm{NO}_{3}^{-}$to TN was $99.2 \pm 1.9 \%$ ) under such low temperature conditions $(276.5 \pm 1.4 \mathrm{~K})$. Thirdly, the $\mathrm{NH}_{3}-$ $\mathrm{HNO}_{3}$ partial pressure production $\left(K_{\mathrm{P}}\right)$ was as low as about $0.1 \mathrm{ppb}^{2}$ (calculated from ISORROPIA-II outputs, depending not only on temperature and $\mathrm{RH}$ but also on sulfate concentration). The value of $K_{\mathrm{P}}$ would remain constant if the temperature, $\mathrm{RH}$ and sulfate concentration remained unchanged. In general, $\mathrm{NH}_{4} \mathrm{NO}_{3}$ was not easy to volatilize into the gas phase under these circumstances.

When TA was reduced by $40 \%$, the average mass concentration of gaseous $\mathrm{NH}_{3}$ decreased from 6.6 to $0.01 \mu \mathrm{g} \mathrm{m}^{-3}$ (from 8.8 to $0.05 \mathrm{ppb}$ ). In order to keep the value of $K_{\mathrm{P}}$ constant in the thermodynamic equilibrium state, the reductions in $\mathrm{NH}_{3}$ increased $\mathrm{HNO}_{3}$, which shifted the particulate$\mathrm{NO}_{3}^{-}$partitioning toward the gas phase. Hence, when $\mathrm{NH}_{3}$ in gas phase was almost completely depleted, $\mathrm{HNO}_{3}$ increased from 0.4 to $15.5 \mathrm{\mu g} \mathrm{m}^{-3}$ (from 0.1 to $5.6 \mathrm{ppb}$ ), leading to a reduction in particulate $\mathrm{NO}_{3}^{-}$from 40.8 to $25.7 \mu \mathrm{g} \mathrm{m}^{-3}$ (a $37.0 \%$ reduction). Meanwhile, $\mathrm{NH}_{4}^{+}$also decreased from 27.9 to $20.6 \mu \mathrm{g} \mathrm{m}^{-3}$, and there was almost no change in sulfate level (decreased from 39.7 to $39.3 \mu \mathrm{g} \mathrm{m}^{-3}$ ), with only a trace amount of $\mathrm{NH}_{4} \mathrm{HSO}_{4}$ produced. This indicated that the 

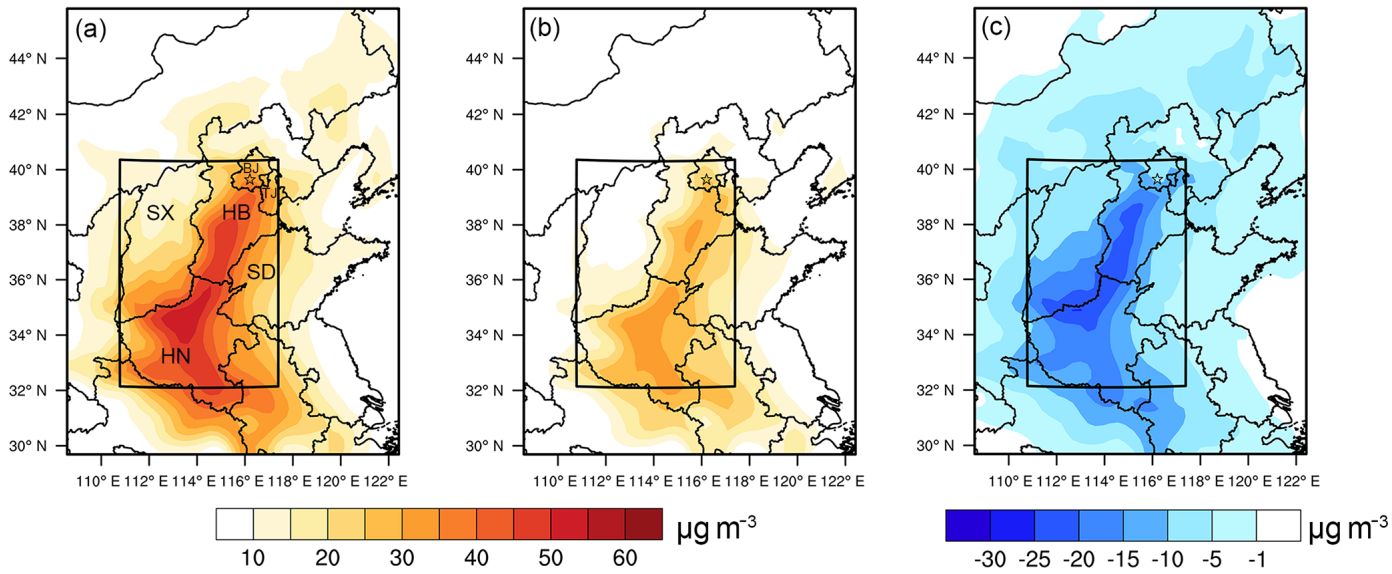

Figure 2. Spatial distribution of particulate- $\mathrm{NO}_{3}^{-}$concentrations in northern China predicted by WRF-Chem from 6 to 10 December 2015 , for (a) the base case, (b) the emission reduction case, and (c) the difference between the base case and the emission reduction case. The scope of this study focuses on the black box, including Beijing (BJ), Tianjin (TJ), Hebei (HB), Shanxi (SX), Shandong (SD) and Henan (HN).

reduction in particulate $\mathrm{NH}_{4}^{+}$and $\mathrm{NO}_{3}^{-}$was mainly due to the reduction in $\mathrm{NH}_{4} \mathrm{NO}_{3}$. The sum of particulate $\mathrm{NO}_{3}^{-}$and $\mathrm{NH}_{4}^{+}$decreased from 68.7 to $46.3 \mu \mathrm{g} \mathrm{m}^{-3}$ (a $32.6 \%$ reduction).

We also conducted WRF-Chem simulations to quantify the impacts of $\mathrm{NH}_{3}$ emission controls on particulate $\mathrm{NO}_{3}^{-}$regionally. A $60 \%$ reduction in livestock $\mathrm{NH}_{3}$ emissions was used as an emission reductions scheme, and Fig. 2 shows the spatial distribution of particulate $\mathrm{NO}_{3}^{-}$under the base case and the emission reduction case. The spatial distribution of particulate $\mathrm{NO}_{3}^{-}$was mainly concentrated in most parts of Henan (HN) and Hebei (HB), with average concentration over $30 \mu \mathrm{g} \mathrm{m}^{-3}$ (included in the black box shown in Fig. 2a). The highest particulate- $\mathrm{NO}_{3}^{-}$concentrations, more than $60 \mu \mathrm{g} \mathrm{m}^{-3}$, were mainly located in central south of Hebei and northern Henan. In the emission reduction case, the mean concentration of particulate $\mathrm{NO}_{3}^{-}$decreased from 30.6 to $18.5 \mu \mathrm{g} \mathrm{m}^{-3}$ (a $39.4 \%$ reduction) in the range of the black box. Meanwhile, the particulate $\mathrm{NH}_{4}^{+}$decreased from 16.3 to $11.7 \mu \mathrm{g} \mathrm{m}^{-3}$ (a $28.1 \%$ reduction). The sum of particulate $\mathrm{NO}_{3}^{-}$and $\mathrm{NH}_{4}^{+}$decreased from 46.9 to $30.2 \mu \mathrm{g} \mathrm{m}^{-3}$ (a $35.6 \%$ reduction). Besides, the sulfate concentration slightly changed from 19.7 to $17.6 \mu \mathrm{g} \mathrm{m}^{-3}$, and $\mathrm{PM}_{2.5}$ concentration dropped from 143.4 to $125.4 \mu \mathrm{g} \mathrm{m}^{-3}$. The largest reductions in particulate $\mathrm{NO}_{3}^{-}$were mainly located in the central north of Henan and central Hebei, where the percentage reduction was generally more than $60 \%$ (shown in Fig. 2b). In some areas with high particulate- $\mathrm{NO}_{3}^{-}$concentrations, particulate $\mathrm{NO}_{3}^{-}$had been effectively reduced by more than $30 \mu \mathrm{g} \mathrm{m}^{-3}$ (shown in Fig. 2c). In these regions, severe haze events occurred frequently due to their large emissions of air pollutants, including $\mathrm{NH}_{3}$ (Wang et al., 2014; Zhao et al., 2017). In addition, $\mathrm{TN}$ was reduced by $34.1 \%$ (from 31.8 to $21.0 \mu \mathrm{g} \mathrm{m}^{-3}$ ), which was in line with the assumption in Sect. 2.3. Correspondingly, TA decreased by $40.7 \%$ (from
17.2 to $10.2 \mu \mathrm{g} \mathrm{m}^{-3}$ ), very close to the reductions in $\mathrm{NH}_{3}$ emission $(40 \%)$. This indicates that it is reasonable to use TA reductions to represent $\mathrm{NH}_{3}$ emission reductions in the ISORROPIA-II simulation.

\subsection{The particulate- $\mathrm{NO}_{3}^{-}$reduction efficiency during the wintertime}

The sensitivity of particulate $\mathrm{NO}_{3}^{-}$to $\mathrm{NH}_{3}$ is often determined by the availability of ambient $\mathrm{NH}_{3}$, which can be represented by the observable indicator (Seinfeld and Pandis, 2006). In this study, we use the observed molar ratio $(R)$ of $\mathrm{TA}$ to the sum of sulfate, total chlorine and $\mathrm{TN}$ minus $\mathrm{Na}^{+}$, $\mathrm{K}^{+}, \mathrm{Ca}^{2+}$ and $\mathrm{Mg}^{2+}$ to represent the availability of ambient $\mathrm{NH}_{3}$ and predict the sensitivity of the particulate $\mathrm{NO}_{3}^{-}$to changes in TN and TA.

$$
R=\frac{\mathrm{TA}}{2 \mathrm{SO}_{4}^{2-}+\mathrm{NO}_{3}^{-}+\mathrm{HNO}_{3}(\mathrm{~g})+\mathrm{Cl}^{-}+\mathrm{HCl}(\mathrm{g})}
$$

The accuracy of $R$ was examined by constructing the isopleths of particulate- $\mathrm{NO}_{3}^{-}$concentrations as a function of TN and TA (shown in Fig. 3). The $\mathrm{NO}_{3}^{-}$concentration was constructed by varying the input concentrations of TA and TN from 0 to $200 \mu \mathrm{g} \mathrm{m}^{-3}$ in increments of $10 \mu \mathrm{g} \mathrm{m}^{-3}$ independently in ISORROPIA-II, while using the observed average value for the other components. Over a range of temperatures $(273-283 \mathrm{~K})$ and RHs (30\%-90\%), the dashed line of $R=1$ divides each isopleth into two regions with a tiny bias, which indicates that $R$ can be used to qualitatively predict the response of the particulate $\mathrm{NO}_{3}^{-}$to changes in concentrations of TN and TA.

On the right side of the dashed line $(R>1)$, particulate$\mathrm{NO}_{3}^{-}$formation is $\mathrm{HNO}_{3}$-limited. The $\mathrm{NH}_{3}$ is surplus and almost all particulate $\mathrm{NO}_{3}^{-}$exists in the aerosol phase. The TA reductions mainly reduce $\mathrm{NH}_{3}$ with negligible effects on 

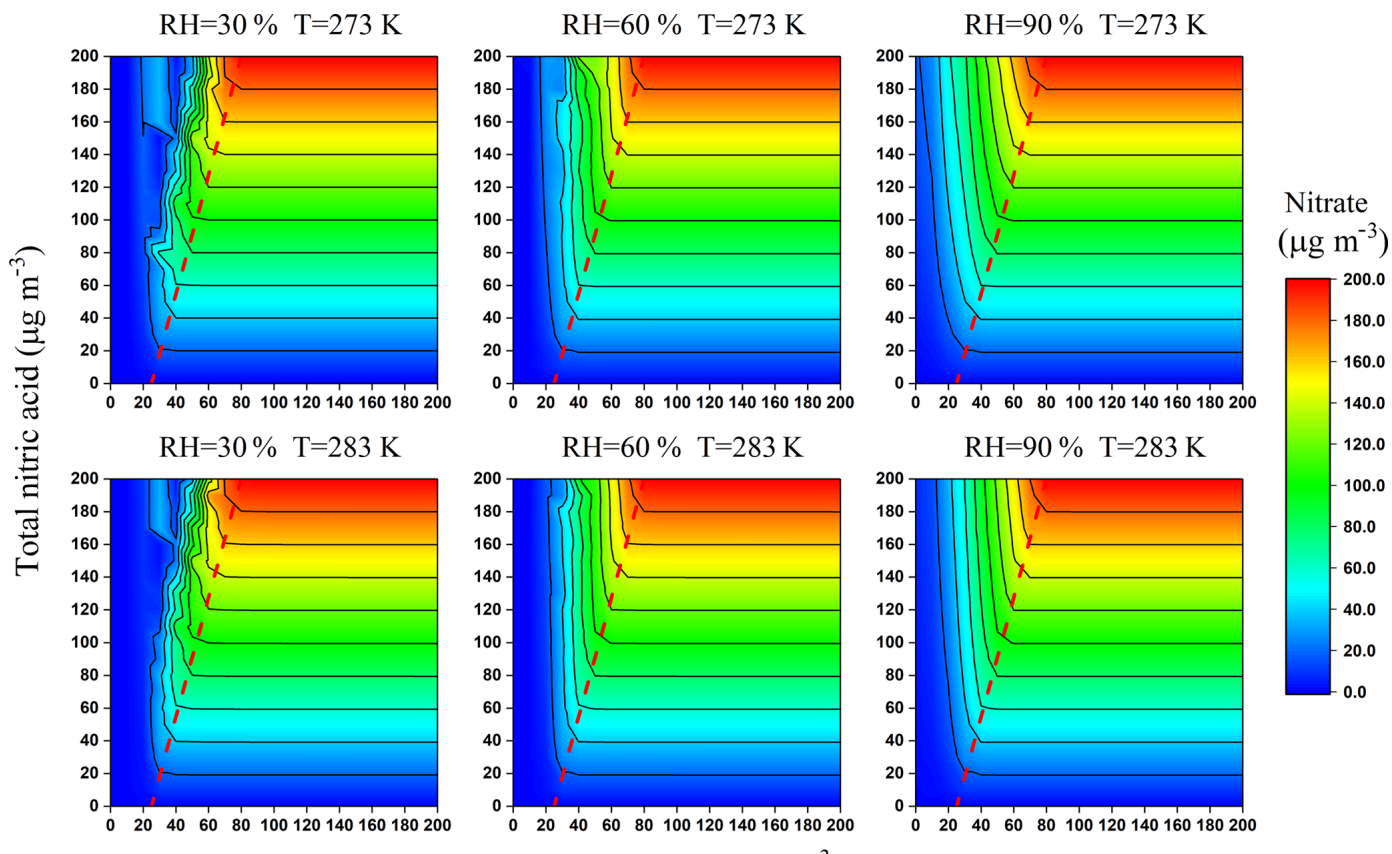

$\left(\mu \mathrm{g} \mathrm{m}^{-3}\right)$
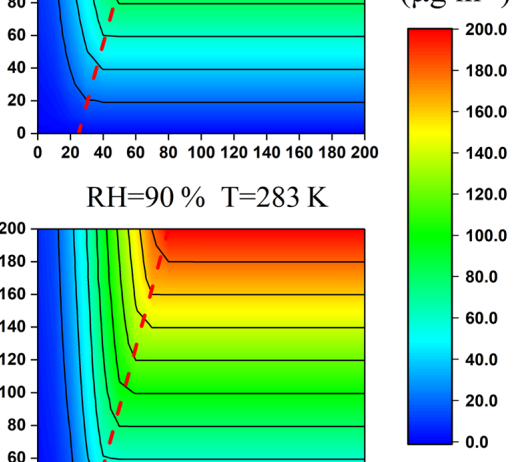

Total ammonia $\left(\mu \mathrm{g} \mathrm{m}^{-3}\right)$

$$
-----\mathrm{R}=1
$$

Figure 3. Isopleths of the particulate- $\mathrm{NO}_{3}^{-}$concentration $\left(\mu \mathrm{g} \mathrm{m}^{-3}\right)$ as a function of $\mathrm{TN}$ and $\mathrm{TA}$ under average severe haze conditions in winter. The concentration of $\mathrm{SO}_{4}^{2-}, \mathrm{Cl}^{-}, \mathrm{K}^{+}, \mathrm{Ca}^{2+}, \mathrm{Na}^{+}$and $\mathrm{Mg}^{2+}$ was $60.2,9.3,0.56,0.04,0.75$ and $0.03 \mu \mathrm{g} \mathrm{m}{ }^{-3}$, respectively. Values are averages from all severe hazes during the observation period.
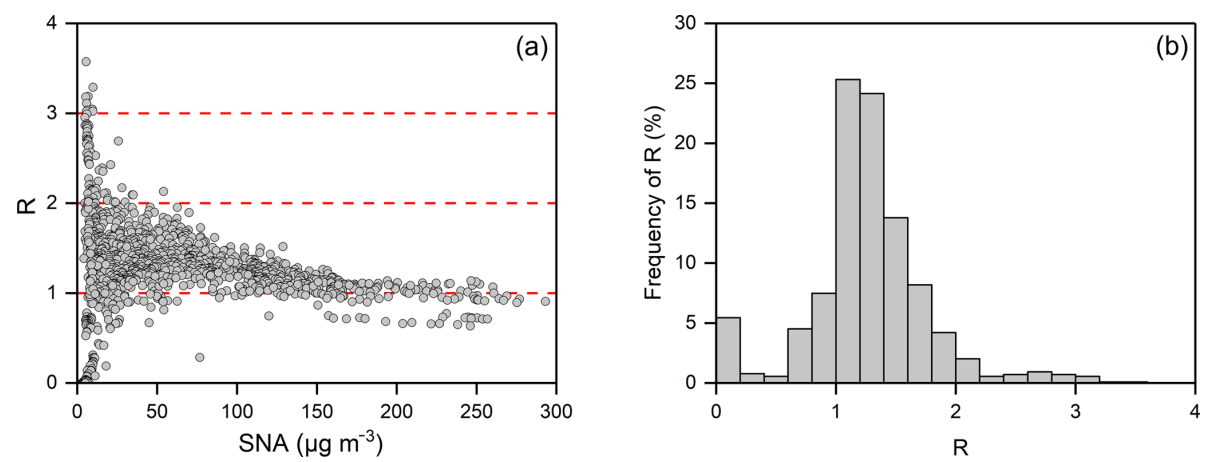

Figure 4. (a) The observed molar ratio $(R)$ and the concentrations of SNA in PKUERS in December 2015 and December 2016. (b) The frequency of $R$ during the same period.

particulate $\mathrm{NO}_{3}^{-}$. By contrast, particulate- $\mathrm{NO}_{3}^{-}$formation is $\mathrm{NH}_{3}$-limited to the left of the dashed line $(R<1)$. There is less $\mathrm{NH}_{3}$ present in the gas phase, and TA reductions could reduce particulate $\mathrm{NO}_{3}^{-}$efficiently. For example, when the concentrations of TN and TA are 100 and $50 \mu \mathrm{g} \mathrm{m}^{-3}$ ( $\mathrm{RH}=60 \%$ and $T=273 \mathrm{~K}$ ), the concentration of particulate $\mathrm{NO}_{3}^{-}$is about $100 \mu \mathrm{g} \mathrm{m}^{-3}$ and the value of $R$ is close to 1 (typical observational values during the severe haze in this study). In such cases, if TA were reduced by $50 \%$ to $25 \mu \mathrm{g} \mathrm{m}^{-3}$, the particulate $\mathrm{NO}_{3}^{-}$would be significantly reduced from 100 to $20 \mu \mathrm{g} \mathrm{m}^{-3}$, an $80 \%$ reduction.
Under the typical winter conditions in northern China, the value of $R$ was generally greater than 1 and gradually declining with the increase in SNA concentrations (shown in Fig. 4a). When the concentration of SNA is greater than $150 \mu \mathrm{g} \mathrm{m}^{-3}$, the values of $R$ become close to and frequently lower than 1 . This indicated that particulate- $\mathrm{NO}_{3}^{-}$formation would easily become $\mathrm{NH}_{3}$-limited under severe haze conditions when $\mathrm{NH}_{3}$ emissions were reduced. In general, particulate $\mathrm{NO}_{3}^{-}$will be reduced effectively by a $40 \%$ reduction in $\mathrm{NH}_{3}$ emissions on the condition that the value of $R$ is less than 1.4 (shown in Fig. S4). This situation accounts for $68.1 \%$ of all of December (shown in Fig. 4b). It should also 
be noted that particulate $\mathrm{NO}_{3}^{-}$is insensitive to a $40 \%$ reduction in $\mathrm{NH}_{3}$ emissions when the value of $R$ is greater than 1.4 (shown in Fig. S4). This situation mainly occurs on relatively clean days (the concentration of SNA is less than $75 \mu \mathrm{g} \mathrm{m}^{-3}$ ), accounting for only $31.9 \%$ of all of December (shown in Fig. 4a, b). Overall, reducing $40 \%$ of $\mathrm{NH}_{3}$ emissions could effectively reduce the levels of particulate $\mathrm{NO}_{3}^{-}$under typical severe winter haze conditions in northern China.

The observed $R$ provides a simple method to rapidly estimate the efficiency of $\mathrm{NH}_{3}$ emission reductions in particulate- $\mathrm{NO}_{3}^{-}$reductions, which can avoid the drawbacks of the air quality model, especially the uncertain estimates of meteorology. However, it also needs to be examined in more detail for specific pollution and meteorological conditions. Therefore, the observed indicator and air quality models should be used in a complementary way to assess the effectiveness of $\mathrm{NH}_{3}$ emission control strategies.

Based on the above analysis, the influence of WRF-Chem simulation biases on particulate- $\mathrm{NO}_{3}^{-}$reduction efficiency simulation mainly depends on the simulation bias of $R$. During the simulation case, the average simulated value of $R$ is 1.3 , which is equivalent to the observed value (1.3). Since WRF-Chem has a good estimation of the availability of ambient $\mathrm{NH}_{3}$, its estimation of the efficiency of particulate$\mathrm{NO}_{3}^{-}$reductions is reliable.

It is noteworthy that the efficiency of particulate- $\mathrm{NO}_{3}^{-}$reductions by $\mathrm{NH}_{3}$ emission controls in northern China during severe winter hazes may be higher than that in the United States and Europe. Compared with our results $\left(40 \% \mathrm{NH}_{3}\right.$ emission reductions lead to about $40 \%$ particulate- $\mathrm{NO}_{3}^{-}$reductions), in the United States and Europe, $\mathrm{NH}_{3}$ emissions often need to be reduced by more than $70 \%$ before particulate $\mathrm{NO}_{3}^{-}$begins to decrease (Pozzer et al., 2017; Guo et al., 2018). This is mainly because the strict emission controls of $\mathrm{SO}_{2}$ and $\mathrm{NO}_{x}$ in these areas lead to a more ammonia-rich environment, which makes particulate $\mathrm{NO}_{3}^{-}$insensitive to $\mathrm{NH}_{3}$ emission reductions.

\section{Conclusions}

In this study, we found that during severe winter haze episodes, the particulate- $\mathrm{NO}_{3}^{-}$formation is $\mathrm{NH}_{3}$-limited, resulting in its high sensitivity to $\mathrm{NH}_{3}$ emission reductions. Meanwhile, livestock $\mathrm{NH}_{3}$ emission control is a very efficient way to alleviate particulate- $\mathrm{NO}_{3}^{-}$pollution during severe winter hazes. The estimations showed that improvements in the manure management of livestock husbandry could effectively reduce total $\mathrm{NH}_{3}$ emissions by $40 \%$ (from 100 to $60 \mathrm{kt}$ ) in northern China in winter. This would lead to a reduction in particulate $\mathrm{NO}_{3}^{-}$by about $40 \%$ (on average from 40.8 to $25.7 \mu \mathrm{g} \mathrm{m}^{-3}$ ) during severe haze conditions.

$\mathrm{NO}_{x}$ emission controls could be a more direct and effective way to reduce particulate $\mathrm{NO}_{3}^{-}$than $\mathrm{NH}_{3}$ emission reductions. However, in northern China, the tar- get of $\mathrm{NO}_{x}$ emission reductions is only about $25 \%$ in the 13th Five-Year Plan (2016-2020) (http://www.gov.cn/ zhengce/content/2017-01/05/content_5156789.htm, last access: 5 January 2019). Due to the dominance of free-range animal rearing systems and the lack of emission controls policies, livestock $\mathrm{NH}_{3}$ emission reductions in China could be practicable. In order to control $\mathrm{PM}_{2.5}$ pollution more effectively in northern China, measures to improve manure management in livestock urgently need to be implemented.

Data availability. The model input data and the $\mathrm{NH}_{3}$ emission inventory used in this study are available from the corresponding author.

Supplement. The supplement related to this article is available online at: https://doi.org/10.5194/acp-19-5605-2019-supplement.

Author contributions. YS, SW and MZ initiated the investigation. $\mathrm{CY}, \mathrm{TZ}$ and MZ conducted the aerosol and gas measurements. ZX, TW and ML performed the modeling analyses. ZX, SW, LZ, CY and MZ wrote and edited the manuscript. MZ, TX, TW, YS, $\mathrm{YP}, \mathrm{MH}$ and $\mathrm{TZ}$ contributed to discussions of the results and the manuscript.

Competing interests. The authors declare that they have no conflict of interest.

Acknowledgements. This study was funded by the National Key R\&D Program of China (2016YFC0201505), the National Natural Science Foundation of China (NSFC) (91644212 and 41675142), the Beijing Science and Technology Project (Z181100005418016), and the National Research Program for Key Issues in Air Pollution Control (DQGG0208).

Edited by: Qiang Zhang

Reviewed by: two anonymous referees

\section{References}

Backes, A. M., Aulinger, A., Bieser, J., Matthias, V., and Quante, M.: Ammonia emissions in Europe, Part II: How ammonia emission abatement strategies affect secondary aerosols, Atmos. Environ., 126, 153-161, https://doi.org/10.1016/j.atmosenv.2015.11.039, 2016.

Balsari, P., Dinuccio, E., and Gioelli, F.: A low cost solution for ammonia emission abatement from slurry storage, Int. Congr. Ser., 1293, 323-326, https://doi.org/10.1016/j.ics.2006.02.045, 2006.

Bessagnet, B., Beauchamp, M., Guerreiro, C., de Leeuw, F., Tsyro, S., Colette, A., Meleux, F., Rouil, L., Ruyssenaars, P., Sauter, F., Velders, G. J. M., Foltescu, V. L., and van Aardenne, J.: Can further mitigation of ammonia emissions reduce exceedances of 
particulate matter air quality standards?, Environ. Sci. Policy, 44, 149-163, https://doi.org/10.1016/j.envsci.2014.07.011, 2014.

Blanchard, C. L. and Hidy, G. M.: Effects of changes in sulfate, ammonia, and nitric acid on particulate nitrate concentrations in the southeastern United States, J. Air Waste Manage., 53, 283290, https://doi.org/10.1080/10473289.2003.10466152, 2003.

Chadwick, D., Sommer, S. G., Thorman, R., Fangueiro, D., Cardenas, L., Amon, B., and Misselbrook, T.: Manure management: Implications for greenhouse gas emissions, Anim. Feed Sci. Tech., 166, 514-531, https://doi.org/10.1016/j.anifeedsci.2011.04.036, 2011.

Chadwick, D., Jia, W., Tong, Y. A., Yu, G. H., Shen, Q. R., and Chen, Q.: Improving manure nutrient management towards sustainable agricultural intensification in China, Agr. Ecosyst. Environ., 209, 34-46, https://doi.org/10.1016/j.agee.2015.03.025, 2015.

de Meij, A., Thunis, P., Bessagnet, B., and Cuvelier, C.: The sensitivity of the CHIMERE model to emissions reduction scenarios on air quality in Northern Italy, Atmos. Environ., 43, 1897-1907, https://doi.org/10.1016/j.atmosenv.2008.12.036, 2009.

Fast, J. D., Gustafson, W. I., Easter, R. C., Zaveri, R. A., Barnard, J. C., Chapman, E. G., Grell, G. A., and Peckham, S. E.: Evolution of ozone, particulates, and aerosol direct radiative forcing in the vicinity of Houston using a fully coupled meteorology-chemistry-aerosol model, J. Geophys. Res.-Atmos., 111, D21305, https://doi.org/10.1029/2005jd006721, 2006.

Fountoukis, C. and Nenes, A.: ISORROPIA II: a computationally efficient thermodynamic equilibrium model for $\mathrm{K}^{+}$$\mathrm{Ca}^{2+}-\mathrm{Mg}^{2+}-\mathrm{NH}_{4}^{+}-\mathrm{Na}^{+}-\mathrm{SO}_{4}^{2-}-\mathrm{NO}_{3}^{-}-\mathrm{Cl}^{-}-\mathrm{H}_{2} \mathrm{O}$ aerosols, Atmos. Chem. Phys., 7, 4639-4659, https://doi.org/10.5194/acp-74639-2007, 2007.

Fu, X., Wang, S. X., Xing, J., Zhang, X. Y., Wang, T., and Hao, J. M.: Increasing Ammonia Concentrations Reduce the Effectiveness of Particle Pollution Control Achieved via $\mathrm{SO}_{2}$ and $\mathrm{NO}_{x}$ Emissions Reduction in East China, Environ. Sci. Technol. Lett., 4, 221-227, 2017.

Geng, G., Zhang, Q., Tong, D., Li, M., Zheng, Y., Wang, S., and $\mathrm{He}$, K.: Chemical composition of ambient $\mathrm{PM}_{2.5}$ over China and relationship to precursor emissions during 2005-2012, Atmos. Chem. Phys., 17, 9187-9203, https://doi.org/10.5194/acp17-9187-2017, 2017.

Gilhespy, S. L., Webb, J., Chadwick, D. R., Misselbrook, T. H., Kay, R., Camp, V., Retter, A. L., and Bason, A.: Will additional straw bedding in buildings housing cattle and pigs reduce ammonia emissions?, Biosyst. Eng., 102, 180-189, https://doi.org/10.1016/j.biosystemseng.2008.10.005, 2009.

Groenestein, C. M. and Van Faassen, H. G.: Volatilization of ammonia, nitrous oxide and nitric oxide in deep-litter systems for fattening pigs, J. Agr. Eng. Res., 65, 269-274, https://doi.org/10.1006/jaer.1996.0100, 1996.

Guo, H., Otjes, R., Schlag, P., Kiendler-Scharr, A., Nenes, A., and Weber, R. J.: Effectiveness of ammonia reduction on control of fine particle nitrate, Atmos. Chem. Phys., 18, 12241-12256, https://doi.org/10.5194/acp-18-12241-2018, 2018.

Harun, S. M. R. and Ogneva-Himmelberger, Y.: Distribution of Industrial Farms in the United States and Socioeconomic, Health, and Environmental Characteristics of Counties, Geography, 2013, 385893, https://doi.org/10.1155/2013/385893, 2013.
Hou, Y., Velthof, G. L., and Oenema, O.: Mitigation of ammonia, nitrous oxide and methane emissions from manure management chains: a meta-analysis and integrated assessment, Global Change Biol., 21, 1293-1312, 2015.

Hristov, A. N., Hanigan, M., Cole, A., Todd, R., McAllister, T. A., Ndegwa, P. M., and Rotz, A.: Review: Ammonia emissions from dairy farms and beef feedlots, Can. J. Anim. Sci., 91, 1-35, 2011.

Huang, X., Song, Y., Li, M. M., Li, J. F., Huo, Q., Cai, X. H., Zhu, T., Hu, M., and Zhang, H. S.: A high-resolution ammonia emission inventory in China, Global Biogeochem. Cy., 26, GB1030, https://doi.org/10.1029/2011gb004161, 2012.

Kang, Y., Liu, M., Song, Y., Huang, X., Yao, H., Cai, X., Zhang, H., Kang, L., Liu, X., Yan, X., He, H., Zhang, Q., Shao, M., and Zhu, T.: High-resolution ammonia emissions inventories in China from 1980 to 2012, Atmos. Chem. Phys., 16, 2043-2058, https://doi.org/10.5194/acp-16-2043-2016, 2016.

Li, C., McLinden, C., Fioletov, V., Krotkov, N., Carn, S., Joiner, J., Streets, D., He, H., Ren, X., Li, Z., and Dickerson, R. R.: India Is Overtaking China as the World's Largest Emitter of Anthropogenic Sulfur Dioxide, Sci. Rep., 7, 14304, https://doi.org/10.1038/s41598-017-14639-8, 2017.

Liu, F., Beirle, S., Zhang, Q., van der A, R. J., Zheng, B., Tong, D., and He, K.: $\mathrm{NO}_{x}$ emission trends over Chinese cities estimated from OMI observations during 2005 to 2015, Atmos. Chem. Phys., 17, 9261-9275, https://doi.org/10.5194/acp-179261-2017, 2017a.

Liu, M. X., Song, Y., Zhou, T., Xu, Z. Y., Yan, C. Q., Zheng, M., Wu, Z. J., Hu, M., Wu, Y. S., and Zhu, T.: Fine particle pH during severe haze episodes in northern China, Geophys. Res. Lett., 44, 5213-5221, https://doi.org/10.1002/2017gl073210, 2017b.

Monteny, G. J. and Erisman, J. W.: Ammonia emission from dairy cow buildings: A review of measurement techniques, influencing factors and possibilities for reduction, Neth. J. Agr. Sci., 46, 225247, 1998.

Ohara, T., Akimoto, H., Kurokawa, J., Horii, N., Yamaji, K., Yan, X., and Hayasaka, T.: An Asian emission inventory of anthropogenic emission sources for the period 1980-2020, Atmos. Chem. Phys., 7, 4419-4444, https://doi.org/10.5194/acp-7-44192007, 2007.

Pandis, S. N. and Seinfeld, J. H.: On the Interaction between Equilibration Processes and Wet or Dry Deposition, Atmos. Environ., 24, 2313-2327, https://doi.org/10.1016/0960-1686(90)90325-H, 1990.

Paulot, F., Jacob, D. J., Pinder, R. W., Bash, J. O., Travis, K., and Henze, D. K.: Ammonia emissions in the United States, European Union, and China derived by highresolution inversion of ammonium wet deposition data Interpretation with a new agricultural emissions inventory (MASAGE_NH 3 ), J. Geophys. Res.-Atmos., 119, 4343-4364, https://doi.org/10.1002/2013jd021130, 2014.

Petersen, S. O., Dorno, N., Lindholst, S., Feilberg, A., and Eriksen, J.: Emissions of $\mathrm{CH}_{4}, \mathrm{~N}_{2} \mathrm{O}, \mathrm{NH}_{3}$ and odorants from pig slurry during winter and summer storage, Nutr. Cycl. Agroecosys., 95, 103-113, https://doi.org/10.1007/s10705-013-9551-3, 2013.

Pinder, R. W., Adams, P. J., and Pandis, S. N.: Ammonia emission controls as a cost-effective strategy for reducing atmospheric particulate matter in the eastern United States, Environ. Sci. Technol., 41, 380-386, https://doi.org/10.1021/es060379a, 2007. 
Pinder, R. W., Gilliland, A. B., and Dennis, R. L.: Environmental impact of atmospheric $\mathrm{NH}_{3}$ emissions under present and future conditions in the eastern United States, Geophys. Res. Lett., 35, L12808, https://doi.org/10.1029/2008g1033732, 2008.

Plautz, J.: Piercing the Haze, Science, 361, 1060-1063, https://doi.org/10.1126/science.361.6407.1060, 2018.

Pozzer, A., Tsimpidi, A. P., Karydis, V. A., de Meij, A., and Lelieveld, J.: Impact of agricultural emission reductions on fine-particulate matter and public health, Atmos. Chem. Phys., 17, 12813-12826, https://doi.org/10.5194/acp-17-12813-2017, 2017.

Seinfeld, J. H. and Pandis, S. N.: Atmospheric Chemistry and Physics: From Air Pollution to Climate Change, 2nd Edition, John Wiley \& Sons, New York, 1202 pp., 2006.

Streets, D. G., Bond, T. C., Carmichael, G. R., Fernandes, S. D., Fu, Q., He, D., Klimont, Z., Nelson, S. M., Tsai, N. Y., Wang, M. Q., Woo, J. H., and Yarber, K. F.: An inventory of gaseous and primary aerosol emissions in Asia in the year 2000, J. Geophys. Res.-Atmos., 108, 8809, https://doi.org/10.1029/2002jd003093, 2003.

Tan, T. Y., Hu, M., Li, M. R., Guo, Q. F., Wu, Y. S., Fang, X., Gu, F. T., Wang, Y., and Wu, Z. J.: New insight into $\mathrm{PM}_{2.5}$ pollution patterns in Beijing based on one-year measurement of chemical compositions, Sci. Total Environ., 621, 734-743, https://doi.org/10.1016/j.scitotenv.2017.11.208, 2018.

Tsimpidi, A. P., Karydis, V. A., and Pandis, S. N.: Response of inorganic fine particulate matter to emission changes of sulfur dioxide and ammonia: The eastern United States as a case study, J. Air Waste. Manage., 57, 1489-1498, https://doi.org/10.3155/1047-3289.57.12.1489, 2007.

Van Damme, M., Clarisse, L., Heald, C. L., Hurtmans, D., Ngadi, Y., Clerbaux, C., Dolman, A. J., Erisman, J. W., and Coheur, P. F.: Global distributions, time series and error characterization of atmospheric ammonia $\left(\mathrm{NH}_{3}\right)$ from IASI satellite observations, Atmos. Chem. Phys., 14, 2905-2922, https://doi.org/10.5194/acp14-2905-2014, 2014.

Vayenas, D. V., Takahama, S., Davidson, C. I., and Pandis, S. N.: Simulation of the thermodynamics and removal processes in the sulfate-ammonia-nitric acid system during winter: Implications for $\mathrm{PM}_{2.5}$ control strategies, J. Geophys. Res.-Atmos., 110, D07S14, https://doi.org/10.1029/2004jd005038, 2005.

Wang, L. T., Wei, Z., Yang, J., Zhang, Y., Zhang, F. F., Su, J., Meng, C. C., and Zhang, Q.: The 2013 severe haze over southern Hebei, China: model evaluation, source apportionment, and policy implications, Atmos. Chem. Phys., 14, 3151-3173, https://doi.org/10.5194/acp-14-3151-2014, 2014.
Wang, Y., Dong, H. M., Zhu, Z. P., Gerber, P. J., Xin, H. W., Smith, P., Opio, C., Steinfeld, H., and Chadwick, D.: Mitigating Greenhouse Gas and Ammonia Emissions from Swine Manure Management: A System Analysis, Environ. Sci. Technol., 51, 45034511, 2017.

Wu, Y. Y., Gu, B. J., Erisman, J. W., Reis, S., Fang, Y. Y., Lu, X. H., and Zhang, X. M.: $\mathrm{PM}_{2.5}$ pollution is substantially affected by ammonia emissions in China, Environ. Pollut., 218, 86-094, https://doi.org/10.1016/j.envpol.2016.08.027, 2016.

Zaveri, R. A., Easter, R. C., and Peters, L. K.: A computationally efficient multicomponent equilibrium solver for aerosols (MESA), J. Geophys. Res.-Atmos., 110, D24203, https://doi.org/10.1029/2004jd005618, 2005.

Zhang, X. Y., Wang, J. Z., Wang, Y. Q., Liu, H. L., Sun, J. Y., and Zhang, Y. M.: Changes in chemical components of aerosol particles in different haze regions in China from 2006 to 2013 and contribution of meteorological factors, Atmos. Chem. Phys., 15, 12935-12952, https://doi.org/10.5194/acp-15-129352015, 2015.

Zhang, L., Chen, Y., Zhao, Y., Henze, D. K., Zhu, L., Song, Y., Paulot, F., Liu, X., Pan, Y., Lin, Y., and Huang, B.: Agricultural ammonia emissions in China: reconciling bottom-up and top-down estimates, Atmos. Chem. Phys., 18, 339-355, https://doi.org/10.5194/acp-18-339-2018, 2018a.

Zhang, R., Sun, X. S., Shi, A. J., Huang, Y. H., Yan, J., Nie, T., Yan, $\mathrm{X}$., and Li, X.: Secondary inorganic aerosols formation during haze episodes at an urban site in Beijing, China, Atmos. Environ., 177, 275-282, https://doi.org/10.1016/j.atmosenv.2017.12.031, 2018b.

Zhao, B., Wu, W., Wang, S., Xing, J., Chang, X., Liou, K.-N., Jiang, J. H., Gu, Y., Jang, C., Fu, J. S., Zhu, Y., Wang, J., Lin, Y., and Hao, J.: A modeling study of the nonlinear response of fine particles to air pollutant emissions in the BeijingTianjin-Hebei region, Atmos. Chem. Phys., 17, 12031-12050, https://doi.org/10.5194/acp-17-12031-2017, 2017.

Zheng, G. J., Duan, F. K., Ma, Y. L., Zhang, Q., Huang, T., Kimoto, T., Cheng, Y. F., Su, H., and He, K. B.: Episode-Based Evolution Pattern Analysis of Haze Pollution: Method Development and Results from Beijing, China, Environ. Sci. Technol., 50, 4632 4641, https://doi.org/10.1021/acs.est.5b05593, 2016. 